\title{
Delimitation of Funga as a valid term for the diversity of fungal communities: the Fauna, Flora \& Funga proposal (FF\&F)
}

\author{
Francisco Kuhar ${ }^{1}$, Giuliana Furci ${ }^{2}$, Elisandro Ricardo Drechsler-Santos ${ }^{3}$, and Donald H. Pfister ${ }^{4}$ \\ ${ }^{1}$ Instituto Multidisciplinario de Biología Vegetal (CONICET-UNC), Universidad Nacional de Córdoba, CC 495, 5000 Córdoba, Argentina; corresponding author \\ e-mail: fkuhar@gmail.com \\ ${ }^{2}$ Fundación Fungi, José Zapiola 8240 E, La Reina, Santiago 7860292, Chile \\ ${ }^{3}$ Programa de Pós-Graduação em Biologia de Fungos, Algas e Plantas (PPGFAP), Departamento de Botânica Universidade Federal de Santa Catarina (UFSC), \\ Florianópolis, Santa Catarina 88040-900, Brasil \\ ${ }^{4}$ Department of Organismic and Evolutionary Biology, Harvard University, 22 Divinity Avenue, Cambridge, MA 02138, USA
}

Abstract: As public policies and conservation requirements for biodiversity evolve there is a need for a term for the kingdom Fungi equivalent to Fauna and Flora. This need is considered to be urgent in order to simplify projects oriented toward implemention of educational and conservation goals. In an informal meeting held during the IX Congreso Latinoamericano de Micología by the authors, the idea of clarifying this matter initiated an extensive search of pertinent terminologies. As a result of these discussions and reviews, we propose that the word Funga be employed as an accurate and encompassing term for these purposes. This supports the proposal of the three Fs, Fauna, Flora and Funga, to highlight parallel terminology referring to treatments of these macrorganism of particular geographical areas. Alternative terms and proposals are acknowledged and discussed.

Key words: conservation, mycobiota, mycota

\section{INTRODUCTION}

The desirability of having a collective term to use for all the fungi present in a region, equivalent to fauna and flora, has increasingly come to be recognized amongst mycologists active in conservation movements. Various suggestions as to an appropriate term to be used have been made, summarized by Hawksworth (2000), but there has been no overall consensus amongst the mycological community as to which should be commended for general use. We recognized this problem during the IX Congreso Latinoamericano de Micología in Lima, Peru, in 2017, and undertook to analyze the options. We concluded that Funga was the most appropriate term, and present our arguments for the adoption of that term here.

\section{ETYMOLOGY}

We propose that the word Funga be used for descriptive, systematic treatments of the fungi of a particular area. This usage parallels that of Fauna and Flora. Fauna and Flora have been in standard use since the time of Linnaeus, whose Flora Lapponica (Linnaeus 1737) was, in the words of Candolle (1813), the "opera prima of the genre Flora". Since classical times, the words Fauna and Flora have appeared referring to mythological and/or literary beings. Of Latin origin, Flora can be found in ancient texts, such as Macrobius, Lactantius and others, referred to as a fertility goddess of flowers, plants, spring and youth (Seyffert 1895). The most probable origin of this cult dates to the Sabine cultures which inhabitated the Latium long before the foundation of Rome (Hornblower et al. 2012). Ovid's mention of Flora in Fasti (V.193-212) gives evidence that Flora is a variant of the Greek deity $\mathrm{X} \lambda$ wpis (Chloris), already mentioned in Homer's work and others (Crusius 1857). This is related to the modern greek $\chi \lambda \omega$ pós (Chloros), refering to the colour "green". The word Fauna also is of classic mythological origin refering to a Latin goddess, the wife, daughter or sister (depending on the source) of Faunus. This is a Latin equivalent of the ancient Greek $\Pi \dot{\alpha} \nu$ (Pan) (Murley 1922). Although alternative origins of this term were suggested by Varro (1996) and Servius (1881), their etymologies were probably coined in a metaphorical sense. The word Funga has appeared in recent times and is without classical antecedents. It is not found in the 10th edition of Ainsworth \& Bisby's Dictionary of the Fungi (Kirk et al. 2008) although it had already been applied by Dörfelt \& Jetschke (2001). It is an artificial linguistic construction, clearly analogous to Fauna and Flora, and based on the Latin word fungus, which in turn derives from the Greek $\sigma \phi \circ \gamma$ ○ (sphongos) for 'sponge'.

The only Greek-Latin deity exclusively related to a fungal entity was the god Robigus (or his female variant Robigo, depending on the source). Etymologically related to the rusts, "Robigus was also regarded as among those gods whom it is a duty to placate so that they deflect the malign influences away from us or the harvests" in the words of Aulus Gellius (Woodard 2010). These rituals took place during the Robigalia which involved games and sacrifices (Beard et al. 1998). However, the relationship of Robigus to the fungal kingdom is anachronistic, since fungi, including the rusts, where not recognised as a group until modern times. The absence of a mythological reference to fungi may be due to the classification of mushrooms as plants, a view held well into the $20^{\text {th }}$ century.

To our knowledge, the first image of a Greek-Latin deity evidently related to mushrooms is found on the title page of Schaeffer's work on the mushrooms of Bavaria and the Palatinate (Schaeffer 1774; Fig. 1). This image is an obvious reference to the goddess Diana (Latin equivalent of Artemis) inspired by its Ephesian representation, whose temple was counted among the seven wonders of the ancient world. The cult of the Ephesian Artemis was related to herbs, fertility, and breeding, 
this is in clear contrast to the other classical concepts of this goddess, which depict her as a hunter (Fleischer 1973). The cult the the Ephesian Artemis was widespread and even the New Testament remarks on the embrace of this belief among the people even in the first century (Acts 19 v. 35). Schaeffer's "Diana-Funga" (in our words) can be interpreted as a pre-romantic recreation that attempts to include the study of mushrooms in the framework of a classic tradition, furthermore the animals present in the tapering pillar of the Ephesian statue were replaced by chanterelles (ubiquitous and very appreciated in Bavaria and the Palatinate) and some agarics or boletes. Also included in this depiction are figures of cherubs collecting mushrooms around the goddess.

\section{BIBLIOGRAPHICAL REFERENCES}

Originally coined by Gravesen (2000), the term Funga was applied to delimit and define the fungal taxa occurring in a certain region (Knudsen \& Vesterholt 2008, Eyjólfsdóttir 2009, Knudsen 2012, Kunttu et al. 2012) or associated with food (Decker \& Nielsen 2005, Filtenborg et al. 1996) or building materials (Gravesen 2000). This infrequent but appropriate use of the term provides a solid base on which to build on the concept of such works and, thus, allowing an unequivocal transmission of scientific knowledge. We think that the use of the word Funga, referring to the taxonomic composition of a fungal community, would be in harmony with the tradition promoted by Linnaeus' Flora. Although first discussed by Hawksworth (2000) in a neutral way, commending "mycobiota" if a term was required at all, in the light of the movement to transition to an independent fungal terminology, as "myco-" was perhaps not as immediately recognized as equivalent to fungi by naturalists in general, he later considered Funga had much to commend it (Hawksworth 2010).

Similar concepts to Funga are delimited also by the composite artificial, Greekrooted terms Mycoflora, Mycobiota or Mycota. Mycoflora is a Greek-Latin composition that was introduced with the recognition that fungi were not plants. Since fungi are now recognized as separate from the plant kingdom it is illogical to apply the term flora to treatments including
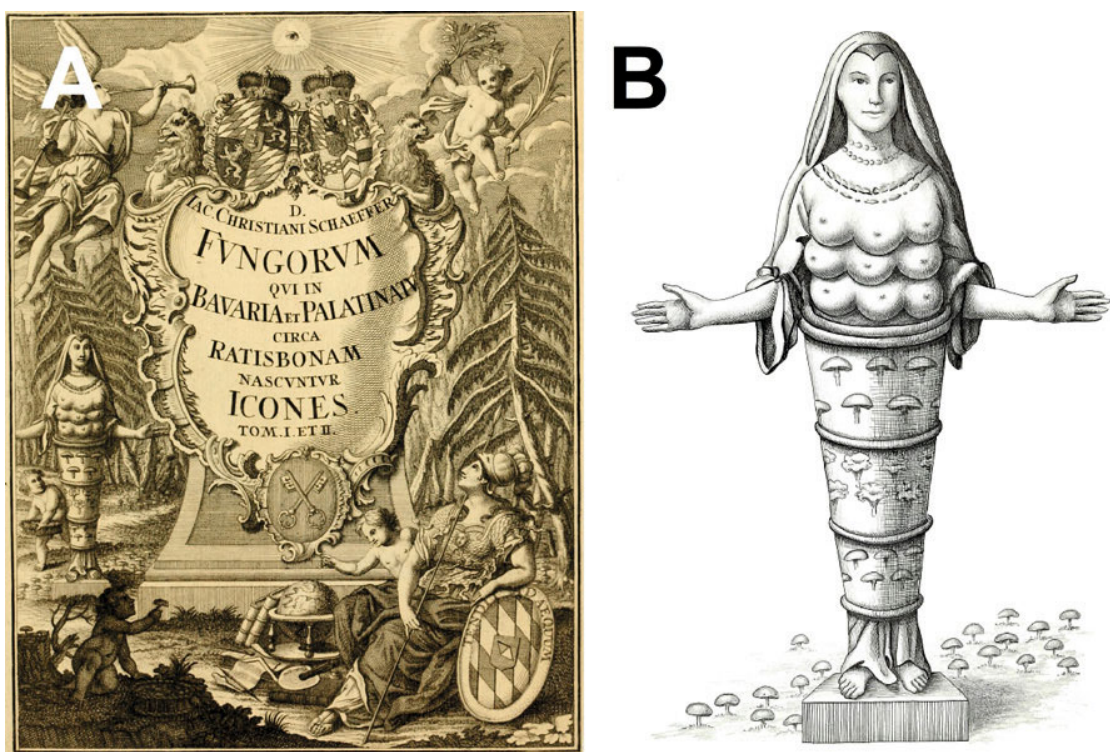

Fig. 1. A. Diana "Funga" as depicted on the cover of Schaeffer (1774). B. Reproduction by the Brazilian artist Claudio Toscan jr.

fungi. Use of the term Mycoflora is a source of confusion for teaching purposes due to the non-correspondence of the roots of the word. Funga provides a purely myco-based term and follows the pattern of recent years to eliminate plant-based terminology and is in accord with the recommendation that fungarium be use rather than herbarium (Hawksworth 2010).

More recently, significant changes were made during the XVIII International Botanical Congress held in Melbourne, Australia, in 2011. One of the most important changes was to rename the Code: International Code of Nomenclature for algae, fungi, and plants (ICN; Turland et al. 2018). This formally recognized organisms treated as fungi as distinct from and at the same level as plants.

The word Mycota has been widely used in technical literature to refer to what we are calling Funga. However, it is considered by many authors (e.g. Allaby 2012) to be a taxonomic synonym of Fungi, the name of the kingdom, and thus its use as an alternative is misleading and not completely accurate. The term Fungi is not a good alternative for Funga, just as Viridiplantae is not an alternative for Flora, nor Animalia for Fauna. Further, "-mycota" is a suffix used to indicate the rank of phylum of all organisms treated as fungi under the ICN (Turland et al. 2018), as in Ascomycota and Basidiomycota, so its use at the rank of kingdom could be misleading as to the intended rank; this was the principle reason this was not favoured by
Hawksworth (2000). Indeed, as a suffix, -mycota remains the termination to be used for phyla applied to all organism treated as fungi for the purposes of nomenclature, and so can be applied to non-fungal eukaryotic organisms such as Oomycota (Arx 1967), Myxomycota (Alexopoulos et al. 1996), and has even in the past been used for some prokaryotes not regulated under the $I C N$, such as Actinomycota (Copeland 1956). The usage of this suffix therefore makes this option more ambiguous and potentially misleading than the terminology derived from the Latin fungus that has not been used to indicate a particular taxonomic rank.

Finally, the term Mycobiota has also been applied to the fungal components of a community and can be considered a synonym of Funga. Although entirely correct, we think that the educational and governmental sectors would better accept a latinized term in accordance with Fauna and Flora. The neo-Greek composition Mycobiota also would present orthographic variations (e.g. Micobiota in Spanish) which would sound strange to the public from different linguistic origins, as it happens with biology - biología. As a response to an inquiry made to the Real Academia Española, the word 'hongos' (Spanish for fungi) was suggested to complete the trilogy of the three mostly macroscopic Kingdoms of life (Cesar Marín, pers. comm.). Unlike Fauna and Flora, the use of this term would be restricted to Spanishspeaking readers, and translations would be needed for every other language. This would 
be out of line with the aim of universality in scientific language.

Finally, we suggest that the incorporation of fungi in educational, political and conservation contexts would be more meaningful and effective through the phrase "Fauna, Flora, and Funga" which would be intelligible for readers of a wide range of linguistic origins and sociocultural sectors. The abbreviation "FF\&F" is also appropriate in the current era of short communications that represent large concepts. The concept of the 3Fs also will assists decision makers in the incorporation of fungi into every aspect of a countries' reference to nature and enable the adoption of policy that incorporates these three larger macroscopic kingdoms.

\section{GRAMMATICAL CONSIDERATIONS}

The word Funga, standing beside Fauna and Flora, must be considered a feminine singular nominative substantive in the first Latin declension. Despite the almost exclusive use in the singular, as in most collective nouns, the singular genitive as well as the plural nominative forms must be Fungae, as it has been used in the plurals Florae (e.g. Jalas \& Suominen 1988, for the singular genitive) or Faunae (e.g. Barbour \& Loveridge 1928, Yeates \& Brid 1994, for the plural nominative).

\section{IMPORTANCE OF TERMINOLOGY FOR CONSERVATION}

Species conservation on a global scale commonly refers to living macroscopic organisms as Fauna and Flora, with the total omission of fungi or any microscopic organisms. Nevertheless, countries like Chile have taken pioneering steps towards an ecosystem view of nature through the incorporation of kingdom Fungi in public policy (República de Chile 2010: Par. 4, Arts. 37-38). This has given the country effective protection of plants, animals, and fungi, but other countries' legislation mentions only Fauna and Flora and sometimes microorganisms, or refers to "wildlife" - which to many equates to vertebrates. By the omission of fungi, these organisms so critical to the maintenance of healthy ecosystem processes, are unrecognized and unrepresented.

The international acceptance of the recognition of the macroscopic organisms of Earth as Fauna, Flora, and Funga paves the way for substantial changes in educational and agricultural policies, amongst others. This will facilitate the incorporation of mycology in matters of national interest, such as conservation, habitat protection, species protection, and education. The use of the 3Fs in overarching international assemblies, such as the International Union for the Conservation of Nature (IUCN) and the Convention on Biological Diversity of the United Nations (CBD), will provide a modern foundation for reference to what is emerging as one of the largest groups of organisms on Earth.

\section{REFERENCES}

Alexopoulos CJ, Mims CN, Blackwell M (1996) Introductory Mycology. $4^{\text {nd }}$ edn. New York: John Wiley \& Sons.

Allaby M (2012) A Dictionary of Plant Sciences. $3^{\text {rd }}$ edn. Oxford: Oxford University Press.

Arx JA von (1967) Pilzkunde: ein kurzer Abriss der Mykologie unter besonderer Berücksichtigung der Pilze in Reinkultur. Lehre: J. Cramer.

Barbour T, Loveridge A (1928) A comparative study of the herpetological Faunae of the Uluguru and Usambara Mountains, Tanganyika Territory with descriptions of new species. Memoirs of the Museum of Comparative Zoology 50: 85-265.

Beard M, North J, Price S (1998) Religions of Rome. Vol. 1. A History. Cambridge: Cambridge University Press.

Copeland HF (1956) The Classification of Lower Organisms. Palo Alto, CA: Pacific Books.

Crusius GC (1857) Vollständiges griechisch-deutsches Wörterbuch über die Gedichte des Homeros und der Homeriden. $5^{\text {th }}$ edn. Leipzig: Hahn.

de Candolle AP (1813) Théorie Élémentaire de la Botanique. Paris: Deterviile.

Decker M, Nielsen PV (2005) The inhibitory effect of Penicillium camemberti and Geotrichum candidum on the associated funga of white mould cheese. International Journal of Food Microbiology 104: 51-60.

Fleischer R (1973) Artemis von Ephesos und verwandte Kultstatuen aus Anatolien und Syrien. Leiden: Brill.

Dörfelt H, Jetschke G (2001) Wörterbuch der Mycologie. Heidelberg: Spektrum Akademischer.

Eyjólfsdóttir GG (2009) Investigation of the funga of Surtsey 2008. Surtsey Research 12: 105-111.
Filtenborg O, Frisvad JC, Thrane U (1996) Moulds in food spoilage. International Journal of Food Microbiology 33: 85-102.

Gravesen S (2000) Microbiology on Indoor Air99 - What is new and interesting? An overview of selected papers presented in Edinburgh, August 1999. Indoor Air 10: 74-80.

Hawksworth DL (2000) Mycobiota, mycota or funga? Mycological Research 104: 1283.

Hawksworth DL (2010) Funga and fungarium. IMA Fungus 1: 9.

Hornblower S, Spawforth A, Eidinow E (2012) The Oxford Classical Dictionary. Oxford: Oxford University Press.

Jalas J, Suominen J (1988) Atlas Florae Europaeae. Vol. 3. Distribution of Vascular Plants in Europe. Cambridge: Cambridge University Press.

Knudsen H, Vesterholt J (2008) Funga Nordica: agaricoid, boletoid and cyphelloid genera. Copenhagen: Nordsvamp.

Knudsen H (2012) Funga Nordica: agaricoid, boletoid, clavarioid, cyphelloid and gastroid genera. $2^{\text {nd }}$ edn. 2 vols. Copenhagen: Nordsvamp.

Kirk PM, Cannon PF, Minter DW, Stalpers JA (2008) Ainsworth \& Bisby's Dictionary of the Fungi. $10^{\text {th }}$ edn. Wallingford: CAB International.

Kunttu P, Kulju M, Kotiranta H (2012) New national and regional biological records for Finland 2. Contributions to the Finnish aphyllophoroid funga (Basidiomycota). Memoranda Societatis pro Fauna et Flora Fennica 88: 61-66.

Linnaeus C (1737) Flora Lapponica. Amsterdam: Salomonem Schouten.

Murley JC (1922) The Cults of Cisalpine Gaul as seen in the inscriptions. Menasha, WI: G. Banta.

República de Chile (2010) Ley 20.417 que modifica la Ley 19.300 sobre Bases Generales del Medio Ambiente. Santiago: Biblioteca del Congreso Nacional de Chile.

Schäffer JC (1774) Fungorum qui in Bavaria et Palatinatu circa Ratisbonam nascuntur icones nativis coloribus expressae. Regensburg: H.G. Zunkel.

Servius MH (1881) In Vergilii carmina comentarii. Medford, MA: BG Teubner.

Seyffert O (1895) A Dictionary of Classical Antiquities: mythology, religion, literature and art. $3^{\text {rd }}$ edn. London: W. Glaisher.

Turland NJ, Wiersema JH, Barrie FR, Greuter W, Hawksworth DL, et al. (eds) (2018) International Code of Nomenclature for algae, fungi, and plants (Shenzhen Code) adopted by the Nineteenth International Botanical Congress Shenzhen, China, July 2017. [Regnum Vegetabile No. 159.] Glashütten: Koeltz Botanical Books.

Varro MT (1996) De lingua latina. Amsterdam: John Benjamins Publishing. 
Woodard RD (2010) Indo-European Sacred Space: Vedic and Roman cult. Urbana, IL: University of Illinois Press.

Yeates GW, Brid A (1994) Some observations on the influence of agricultural practices on the nematode faunae of some South Australian soils. Fundamental and Applied Nematology 17: 133-145. 